\title{
Effect of Soybean-based Food Supplement on Insulin and Glucose Levels in Type 2 Diabetes Mellitus Patients
}

\author{
Akhmad Edy Purwoko1, Indwiani Astuti 2, Ahmad Husain Asdie³ ${ }^{3}$, Sugiyanto ${ }^{4}$
}

1. Department of Pharmacology and Toxicology, Faculty of Medicine and Health Sciences, Universitas Muhammadiyah Yogyakarta, Indonesia, Jl. Brawijaya, Bantul, DI Yogyakarta 55183

2. Department of Pharmacology and Therapy, Faculty of Medicine - Public Health and Nursing, Universitas Gadjah Mada Yogyakarta, Indonesia, Skip Utara 55281

3. Department of Internal Medicine, Dr. Sardjito Central General Hospital Yogyakarta, Indonesia, Jl. Kesehatan No.155281

4. Department of Pharmacology and Clinical Pharmacy, Faculty of Pharmacy, Universitas Gadjah Mada, Yogyakarta, Indonesia, Skip Utara 55281

Info Article
Submitted: 09-04-2019
Revised: 25-06-2019
Accepted: $19-08-2019$
*Corresponding author
Akhmad Edy Purwoko
Email:
akhmadep@umy.ac.id
akhmadep@gmail.com

\section{Info Article}

Revised: 25-06-2019

*Corresponding author Akhmad Edy Purwoko

akhmadep@umy.ac.id akhmadep@gmail.com

\begin{abstract}
Administration of soy may stimulate increase levels of glucagon-like peptide 1 (GLP-1). Giving soy supplements to people with diabetes can reduce blood glucose levels significantly. However, no studies have shown this reduction effect of glucose level back to normal levels. This study aimed to determine the blood insulin and glucose levels after supplementation of soybean-based food supplements in patients with type 2 diabetes mellitus (T2DM) and the sequencee of DNA of GLP-1 gene. This experimental study was a randomized, treatment controlled; open clinical trial study conducted by comparing the group treated with soybean supplement products containing $18 \mathrm{~g}$ protein and the group of placebo. Seventy-six, subjects with T2DM were recruited from Muhammadiyah Gamping Hospital and PERSADIA Gymnastics, Yogyakarta, based on the inclusion and exclusion criteria. All subyects were grouped randomly into the supplement group and placebo group. Blood sampling was drawn at $8 \mathrm{~h}$ fasting, $2 \mathrm{~h}$ after administration of supplement and $2 \mathrm{~h}$ after administration of $75 \mathrm{~g}$ glucose. The determination of blood insulin and glucose level and DNA sequencing were performed. Blood insulin level $2 \mathrm{~h}$ after supplement administration (mean \pm SEM) increased $5.3 \pm 0.8 \mu \mathrm{IU} / \mathrm{mL}(\mathrm{n}=37)$ while placebo decreased $0.9 \pm 0.4 \mu \mathrm{IU} / \mathrm{mL}(\mathrm{n}=39)$ which was significantly different $(p<0.05)$. In both groups blood glucose levels incresed as much as $130.0 \pm 11.5 \mathrm{mg} / \mathrm{dl}(\mathrm{n}=37)$ and $146.7 \pm 8.2 \mathrm{mg} / \mathrm{dL}(\mathrm{n}=39)(p>0.05)$, for the supplement treated and placebo groups, respectively. DNA sequencing shows a nucleotide variation of GLP-1 (37 amino acid) in Javanese T2DM. It may be concluded that administration of soybean-based supplements containing $18 \mathrm{~g}$ protein increased blood insulin levels and decreased blood glucose levels.

Keywords: soybean supplements, insulin, blood glucose, type 2 diabetes mellitus, GLP-1 gene
\end{abstract}

\section{INTRODUCTION}

The International Diabetes Federation (2015) estimates that people with diabetes mellitus (DM) in the world reached 415 million in 2015 and will increase to 642 million by 2040 . Ten countries with the largest population of DM sufferers in the world are India, China, America, Indonesia, Japan, Pakistan, Russia, Brazil, Italy and Bangladesh (Khardori, 2016). DM is a risk factor for cardiovascular disease. It may be controlled by treatment with anti-diabetic drugs and dietary restrictions (Balitbangkes, 2013). DM management is conducted by the efforts of non-pharmacologic and pharmacologic treatment administration. Non-pharmacological interventions involve applying healthy lifestyles and pharmacological interventions by administering drugs orally and/or injections (PERKENI, 2015). Encouragement of herbal medicine (jamu) research based on health services promoted by Indonesian government 
since 2010 has increased the use of herbal medicine for patient services by the medical profession. This approach requires support of scientific studies on efficacy and safety the herbal medicines (Delima et al., 2012; Herman et al., 2013).

Two hours after administration of soy supplements to people with T2DM showed postprandial glucose levels were significantly lower compared to controls $(p<0.05)$ (Chang et al., 2008; Kwak et al., 2010). Soy milk can reduce blood glucose levels in people with diabetes mellitus (Cahyono, 2011). Giving soy milk for 14 days decreases fasting blood glucose levels in prediabetes women (Sinaga \& Wirawanni, 2013). Soybean supplements can reduce blood glucose levels in diabetic mice and increase white blood cells compared to the normal saline control group (Sada et al., 2013). Chang et al. (2013) reviewed hundreds of papers that discussed the structure, activity, and mechanisms of the actions of various plant chemical compounds for the treatment of type 2 diabetes mellitus (T2DM). Among plants that have the effect of improving the condition of hyperglycemia in the models and in patients those with T2DM are soybean plants. Giving soy flour fortified bread did not have a significant effect on the metabolic profile including fasting glucose levels, cholesterol, triglycerides, LDL cholesterol, and HDL cholesterol compared to the usual diet in diabetic patients (Moghaddam et al., 2014). Administration of $280 \mathrm{~mL}$ soy milk per day for 14 days can reduce blood sugar levels of people with type 2 diabetes mellitus compared to the placebo control group (Baequny et al., 2015). The habit of consuming phytoestrogens, especially in the form of whole food sources such as soybeans and flaxseed, can be considered as a healthy diet for prevention and management of type 2 DM (Talaei, 2015). Isoflavone intake is associated with a lower risk of T2DM in US people who usually consume small to moderate amounts of soy foods (Ding et al., 2016). Consumption of soy and cow's milk induces a decrease in similar glycemic responses (Sun et al., 2016). Supplementation of soy protein more than 6 months significantly reduces Fasting Plasma Glucose, LDL-Cholesterol in T2DM and metabolic syndrome (Zhang et al., 2016). High intake of soybeans and isoflavones can reduce the risk of lower type 2 diabetes in Vietnamese adults (Nguyen et al., 2017). Administration of 15g of soy protein with $66 \mathrm{mg}$ of isoflavones improved significant glycemic control compared to $15 \mathrm{~g}$ of soy protein without isoflavones (Sathyapalan et al.,
2017). The combination of soybean and ginger rhizome extract reduced blood glucose levels better than single soybean seed extract in diabetic mice (Purnomo, 2018). Soy products may be associated with a lower risk of T2DM but requiring further studies that focuses on the dose-response and mechanism of action (Li et al., 2018).

Treatment of soybeans containing $50 \mathrm{~g}$ of protein increased GLP-1 levels by approximately $6 \mathrm{pg} / \mathrm{mL}$ at $30 \mathrm{~min}$ and remained at almost the same level for up to 2-3h after administration with a significant difference compared to glucose in overweight (Bowen etal., 2006). The administration of macronutrients containing soybeans increase levels of glucagon-like peptide 1 (GLP-1) (Douglas et al., 2015). (GLP-1) is released by intestinal L-cells after stimulating nutrients and regulating glucose levels by stimulating insulin secretion (Janus et al., 2019). Genistein stimulate secretion of insulin through cAMP-dependent protein kinase pathway (Liu et al., 2006). Amino acids play an important role in stimulating GLP-1 (Mansour et al., 2013). Bioactive of soy hydrolyzates stimulate an increase in GLP-1 (Tulk et al., 2014). Genistein activates AMPK so that it can reduce insulin resistance (Chang et al., 2013). AMPK alters the transcription and secretion of GLP-1 in intestinal secretin tumor cell line (STC-1) culture (Jiang et al., 2016). Soy milk increases incretin levels (GLP-1 and GIP) which have an effect on reducing blood glucose levels (Sun et al., 2016).

Although the effect of giving soybeans in reducing blood glucose levels in people with T2DM has been demonstrated an adequate clinical evidence is needed for its therapeutic use in medicinal treatments. Therefore, the study was conducted to determine how much insulin and blood glucose levels is altered in T2DM by administration of soy-based supplements.

\section{MATERIALS AND METHODS}

This experimental study was performed by randomized, controlled treatment using an open clinical trial design comparing treatment groups administered soybean supplement products containing $18 \mathrm{~g}$ of protein to control groups given placebo (water) in patients with T2DM. The subjects of the study were 76 people with T2DM recruited from The Hospital of PKU Muhammadiyah Gamping, Yogyakarta and the PERSADIA gymnastics group who fulfilled the inclusion and exclusion criteria. All subjects were willing to take part in the study by completing informed consent forms. The participants were 
grouped randomly into 2 groups of supplement treatment and placebo control. Blood samples were drawn after $8 \mathrm{~h}$ fasting and at $2 \mathrm{~h}$ after administration of supplement product and or placebo. The third blood sampling were taken $2 \mathrm{~h}$ after $75 \mathrm{~g}$ glucose loading for measuring insulin and blood glucose. Levels and DNA sequencing of the the gene of GLP-1 (37 amino acids).

The subjects were selected based on the inclussion and the exclussion criteria.

Confounding variables include age, body mass index, lipid profile, and drug use were recorded. Age $>45$ years is a risk factor in the development of diabetes mellitus, obesity especially central obesity is closely related to the development of type 2 DM can be measured by body mass index. Obesity is also closely related to a person's lipid profile so it needs attention for not to interfering to the variables measured. The use of insulin or oral hypoglycemic agents that may interfere glucose level should be controlled. Therefore, the blood sampling and the administration of supplement were conducted at the time after the patients were fasting for at least 10 hours or after the last dose of anti-hypoglycemic agent and or insulin. Efforts to minimize the influence of confounding factors were randomly allocated subjects into the study group or where possible avoiding these factors in the study.

\section{Instruments}

The equipment used in the study were Venopuncture and injection syringes used for taking blood sampling, EDTA tubes used for blood collection, cooler boxes, Elisa readers for insulin testing, and GENIUS clinical laboratory devices for blood glucose levels.

\section{Material}

A factory-made soy supplement product is obtained from market. Thirty five (35) g of powder per serving mixed with $250 \mathrm{~mL}$ of water with a shaker to obtain a protein content of 18g. To measure insulin levels an ELISA kit was used from CALBIOTECH $®$ while the blood glucose level examinations used Glu Reagent Kit from Shenzhen Genius Electronic Co. Ltd. DNA template preparation of GLP-1 gene firstly was conducted by DNA isolation used Blood Genomic DNA Extraction Mini Kit With Proteinase from Favorgen Biotech Corp. Polymerase Chain Reaction (PCR) was performed used upstream oligonucleotide primer (forward) 5'CTCGCCTTCCTCGGCC3' and downstream oligonucleotide primer (reverse) 3'GAATAACATTGCCAAACGTCACG5' refers to coding region accession no NC_000002.12 according to exon 4 glucagon preproprotein DNA, go taq ${ }^{\circledR}$ green master mix $2 \times 1.25 \mathrm{~mL}$ and nuclease free water.

\section{Treatment of the subjects:}

At the time of the study, subjects were available to the Clinical Laboratory of The Hospital of PKU Muhammadiyah, Gamping, Yogyakarta, for fasting blood collection at 06.00-07.00AM. Subsequently, all subjects were given either a glass of soybean supplement or a glass of water to the treatment group or to the placebo group, respectively. The suplement were given at $10 \mathrm{~h}$ after the last dosing of antidabetic agent. Two hours after taking supplement or placebo, the second blood sampling was taken. The first and the second blood samples were analyzed for insulin and glucose level. After the second blood sampling, all the subjects took 2 pieces of white bread and drank a glass of sweet milk equivalent to $75 \mathrm{~g}$ of glucose. Two hours after eating white bread and drinking sweet milk blood samples were drawn again for the third time to measure the $2 \mathrm{~h}$ postprandial blood glucose as glucose tolerance tests. Determination of insulin was performed by ELISA in the Biomedical Laboratory of FM-PHN UGM. The GLP-1 (37 amino acid) gene sequencing was performed by 1st BASE DNA Sequencing Division of First Base Laboratories Sdn Bhd Malaysia.

\section{Polymerase Chain Reaction (PCR) for c-DNA of GLP1}

The PCR protocol was put in $30 \mu \mathrm{L}$ go taq ${ }^{\circledR}$ master mix, $2 \mu \mathrm{L}$ primer forward, $2 \mu \mathrm{L}$ primer reverse, $22 \mu \mathrm{L}$ nuclease-free water (NFW) and $4 \mu \mathrm{L}$ DNA template into $2 \mathrm{~m}$ PCR tubes and then place the tubes in heat block of thermo cycler and proceed with the thermal cycler setting: $95^{\circ} \mathrm{C} 5 \mathrm{~min}$ for denaturation, 40 cycles $\left(95^{\circ} \mathrm{C} 1 \mathrm{~min}, 57^{\circ} \mathrm{C} 1 \mathrm{~min}\right.$ annealing temperature, $72^{\circ} \mathrm{C} 1 \mathrm{~min}$ ), $70^{\circ} \mathrm{C} 5 \mathrm{~min}$ for extension and $4^{\circ} \mathrm{C}$ indefinitely, finally the PCR result was observed by gel electrophoresis.

PCR was conducted in biomedical laboratory of Faculty of Medicine - Public Health and Nursing (FM-PHN) UGM. Subsequently, The PCR results were sent to First Base Laboratories in Malaysia. Cyclesequencing, purification after cycle sequencing and capillary electrophoresis were conducted at the 1st BASE DNA Sequencing Division of First Base Laboratories Sdn Bhd Malaysia. 
Table I. Characteristic of the subjects

\begin{tabular}{llccc}
\hline & Variable & Suplement Group & Placebo Group & Statistic significans \\
\hline Sex J/P & $18 / 19$ & $18 / 21$ & $\mathrm{P}>0.05$ \\
& Age (years) & $56.6 \pm 1.3$ & $57.6 \pm 1.4$ & $\mathrm{P}>0.05$ \\
& Length of diagnose of & $7.8 \pm 0.0$ & $7.9 \pm 1.1$ & $\mathrm{P}>0.05$ \\
& DM (years) & & & \\
& Body height (cm) & $159 \pm 0.01$ & $158 \pm 0.01$ & $\mathrm{P}>0.05$ \\
& Body weight (kg) & $64.6 \pm 2.3$ & $64.56 \pm 1.8$ & $\mathrm{P}>0.05$ \\
& BMI & $25.0 \pm 0.6$ & $25.1 \pm 0.6$ & $\mathrm{P}>0.05$ \\
Blood presure & Sistolik & $140.3 \pm 2$. & $144.64 \pm 2.7$ & $\mathrm{P}>0.05$ \\
& Diastolik & $77.2 \pm 1.5$ & $80.4 \pm 2.2$ & $\mathrm{P}>0.05$ \\
& Cholesterol level & $219.8 \pm 11.8$ & $19.24 \pm 10.1$ & $\mathrm{P}>0.05$ \\
& HDL & $46.5 \pm 1.7$ & $47.7 \pm 1.8$ & $\mathrm{P}>0.05$ \\
& LDL & $126.1 \pm 7.1$ & $113.4 \pm 7.5$ & $\mathrm{P}>0.05$ \\
& Triglycerides & $197.6 \pm 20.5$ & $218.9 \pm 30.0$ & $\mathrm{P}>0.05$ \\
OHA & 26 & 24 & $\mathrm{P}>0.05$ \\
& OHA + insulin & 11 & 15 & $\mathrm{P}>0.05$ \\
\hline
\end{tabular}

*Numerik data were tested by t-test Man Withney; ${ }^{*}$ Categorical data were tested by Chi-square; OHA = oral hypoglycemic agent

Table II. Blood Insulin Levels glucose

\begin{tabular}{|c|c|c|c|c|c|c|}
\hline \multirow{2}{*}{ Group } & \multicolumn{3}{|c|}{$\begin{array}{l}\text { Mean } \pm \text { SEM of Blood Insulin Level } \\
(\mu \mathrm{IU} / \mathrm{mL})\end{array}$} & \multicolumn{3}{|c|}{$\begin{array}{c}\text { Mean } \pm \text { SEM of Blood Glucose Level } \\
(\mathrm{mg} / \mathrm{dL})\end{array}$} \\
\hline & $\begin{array}{c}\text { Supplement } \\
n=37\end{array}$ & $\begin{array}{c}\text { Placebo-H2O } \\
n=39\end{array}$ & $\mathrm{p}$-value & $\begin{array}{c}\text { Supplement } \\
n=37\end{array}$ & $\begin{array}{c}\text { Placebo- } \mathrm{H}_{2} \mathrm{O} \\
n=39\end{array}$ & $\mathrm{p}$-value \\
\hline Fasting & $11.8 \pm 2.5$ & $14.9 \pm 2.3$ & $>0.05$ & $192.1 \pm 13.7$ & $189.4 \pm 11.2$ & $>0.05$ \\
\hline $\begin{array}{l}\text { Post } \\
\text { supplementation }\end{array}$ & $17.0 \pm 2.8$ & $14.0 \pm 2.3$ & $>0.05$ & $221.0 \pm 14.9$ & $181.1 \pm 11.6$ & $<0.05$ \\
\hline Increase & $5.3 \pm 0.8$ & $(0.9 \pm 0.4)$ & $<0.05$ & $351.0 \pm 19.8$ & $327.5 \pm 14.3$ & $>0.05$ \\
\hline
\end{tabular}

SEM: Standard Error Mean

Capillary electrophoresis results in the form of AB1 files analyzed by BioEdit Sequence Alignment Editor for Windows. Sequencing of GLP-1 (37 amino acid) gene used Applied Bio-systems automated DNA sequencing which consists of 5 step includes DNA template preparation, cycle sequencing, purification after cycle sequencing, capillary electrophoresis.

\section{RESULTS AND DISCUSSION}

There are no significant differences were found between the placebo and the supplement groups in the term of variables which may affect blood glucose level and or insulin level such as age, sex, body weight and BMI, profile lipids, the length of diagnose of DM. Not any subjects involved was categorized as obesity. Some of the subjects are used to administer oral hypoglycemic agent or insulin or combination of the two, but at the time of having supplementation was assumed that the effect of all types of anti-diabetic agent were neglected (Table I).

Fasting insulin levels in the supplement group were $11.8 \pm 2.5 \mu \mathrm{IU} / \mathrm{mL}$ while the placebo group was $14.9 \pm 2.3 \mu \mathrm{IU} / \mathrm{mL}$, and the difference between them was statistically insignificant (Table II) Insulin levels in the treatment group after supplementation with soybean-based supplements increased to $17.0 \pm 2.8 \mu \mathrm{IU} / \mathrm{mL}$ while the placebo group levels was still to be $14.0 \pm 2.3 \mu \mathrm{IU} / \mathrm{mL}$. The increase in insulin levels in the supplement group was $5.3 \pm 0.8 \mu \mathrm{IU} / \mathrm{mL}$ and the decrease in the placebo group insulin level was $0.9 \pm 0.4 \mu \mathrm{IU} / \mathrm{mL}$. The changes of insulin level between the two groups was significant different $(p<0.05)$.

The average fasting blood glucose levels in both the supplementary and placebo treatment groups were above the normal value of fasting glucose levels according to PERKENI, $2015 \quad(>126 \mathrm{mg} / \mathrm{dL}) \quad$ (Table II). 
Table III. Increase in blood glucose levels after supplementation and $2 \mathrm{~h}$ postprandial.

\begin{tabular}{lccc}
\hline \multirow{2}{*}{ Group } & \multicolumn{3}{c}{ Mean \pm SEM of Increase Blood Glucose Level (mg/dL) } \\
\cline { 2 - 4 } & Supplement $\mathbf{n = 3 7}$ & Placebo- $\mathbf{H}_{\mathbf{2}} \mathbf{O} \mathbf{n}=\mathbf{3 9}$ & $\mathbf{p}$-value \\
\hline Post Treatment (supplementation) & $28.9 \pm 6.6$ & $(7.8 \pm 5.5)$ & $<0.05$ \\
2h postprandial & $130.0 \pm 11.5$ & $146.7 \pm 8.2$ & $>0.05$ \\
\hline
\end{tabular}

SEM: Standard Error Mean

Tabel IV. Blood Insulin Level $(\mu \mathrm{IU} / \mathrm{mL})$ and Blood Glucose Level $(\mathrm{mg} / \mathrm{dL})$. Subject treated with insulin excluded

\begin{tabular}{lcccccc}
\hline \multirow{2}{*}{ Group } & \multicolumn{3}{c}{ Blood Insulin Level $(\boldsymbol{\mu U} / \mathbf{m L}$} & \multicolumn{3}{c}{ Blood Glucose Level $(\mathbf{m g} / \mathbf{d L})$} \\
\cline { 2 - 7 } & $\begin{array}{c}\text { Suplement group } \\
\mathbf{N = 2 6}\end{array}$ & $\begin{array}{c}\text { Placebo } \\
\mathbf{N = 2 4}\end{array}$ & $\mathbf{p}$-value & $\begin{array}{c}\text { Suplement group } \\
\mathbf{N = 2 6}\end{array}$ & $\begin{array}{c}\text { Placebo } \\
\mathbf{N = 2 4}\end{array}$ & p-value \\
\hline Fasting & $9.5 \pm 2.9$ & $13.5 \pm 3.0$ & $>0.05$ & $212.3 \pm 15.8$ & $182.3 \pm 13.8$ & $>0.05$ \\
Post Suplement & $15.2 \pm 3.1$ & $12.9 \pm 2.9$ & $>0.05$ & $237.3 \pm 18.8$ & $170.8 \pm 11.0$ & $<0.05$ \\
2h postprandial & & & & $355.3 \pm 25.5$ & $304.5 \pm 15.0$ & $>0.05$ \\
Increase & $5.7 \pm 1.0$ & $(0.6 \pm 0.5)$ & $<0.05$ & & & \\
\hline
\end{tabular}

Tabel V. Increased of Blood Glucose Level (mg/dL) after supplementation and $2 \mathrm{~h}$ post prandial. Subject treated with insulin excluded

\begin{tabular}{lccc}
\hline Group & Suplement group N=26 & Placebo N=24 & p-value \\
\hline Post Suplement & $25.0 \pm 7.7$ & $(10.8 \pm 7.5)$ & $<0.05$ \\
2h post prandial & $118.0 \pm 10.7$ & $146.7 \pm 8.2 .0$ & $>0.05$ \\
\hline
\end{tabular}

However, there is no significant differences of the blood glucose level between the two groups ( $p>0.05)$. After supplementation of soybean supplement, blood glucose levels increased to $221.0 \pm 14.9 \mathrm{mg} / \mathrm{dL}$ (mean \pm SEM) while in the placebo group there was a decrease to $181.1 \pm 11.6 \mathrm{mg} / \mathrm{dL} \quad($ mean \pm SEM). The mean of the two groups were significantly difference $(p<0.05)$. The blood glucose levels after treatment of the supplement increased by $28.9 \pm 6.6 \mathrm{mg} / \mathrm{dL}$ compared to the placebo group in which the blood glucose level decreased by $7.8 \pm 5.5 \mathrm{mg} / \mathrm{dL}$ $(p<0.05) \quad$ (Table III). Blood glucose level in supplement group increased may be caused by serving of supplement of soybean-based contain approximately $11 \mathrm{~g}$ carbohydrate which could be metabolized into glucose.

Soybean ingredient contain protein and isoflavon of genistein. Protein in gastrointestinal tract were brook down into amino acid. Amino acid, glucose and genistein have an effect to stimulate secretion of GLP-1 that stimulate beta cell pancreas to release insulin. Therefore, after given soybean supplement in the supplement group insulin levels should increase and accordingly glucose levels decrease. However in this study the soybean suplement resulted in the increase of glucose levels (Tabel II). It could not be explained the logic of this phenomena. Administration of one serving of supplements made from soybeans containing 18 grams of protein can be given as a substitute for one meal without concurrent antidiabetic drugs if the basal glucose level is normal because the increase in blood glucose levels after administration is quite low with an average increase of $28.9 \pm 6.6 \mathrm{mg} / \mathrm{dL}$.

The average postprandial glucose level of the supplement group was $351.0 \pm 19.8 \mathrm{mg} / \mathrm{dL}$ compared with the placebo group of $327.5 \pm 14.3 \mathrm{mg} / \mathrm{dL}$ and this difference was not significant $(p>0.05)$. Blood glucose levels after $2 \mathrm{~h}$ postprandial in the supplement group appeared to be higher than the placebo group because at the beginning in the supplement group showed higher glucose level than in the placebo group (Table III). After $2 \mathrm{~h}$ postprandial with $75 \mathrm{~g}$ glucose loading and after soybean supplement treatment showed that in the supplement group there was an increase in blood glucose levels by $130.0 \pm 11.5 \mathrm{mg} / \mathrm{dL}$, this was comparable to the increase the glucose level in the placebo group, which the increase was $146.7 \pm 8.2 \mathrm{mg} / \mathrm{dL}$ ( $p>0.05$ ). 


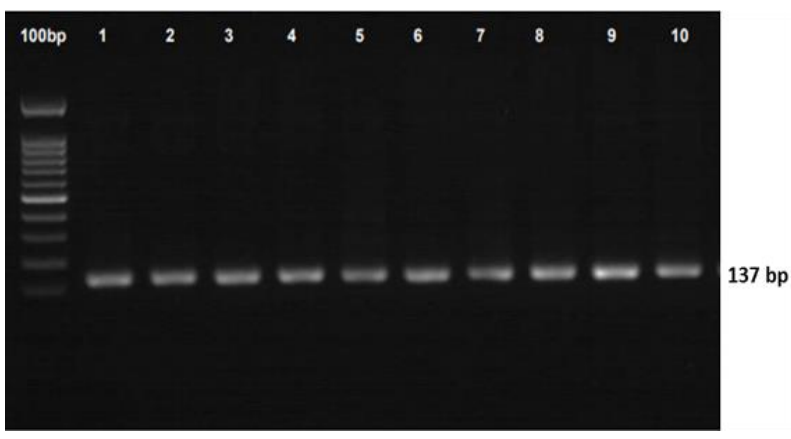

Figure 1. Gel electrophoresis PCR of DNA of GLP-1 gen

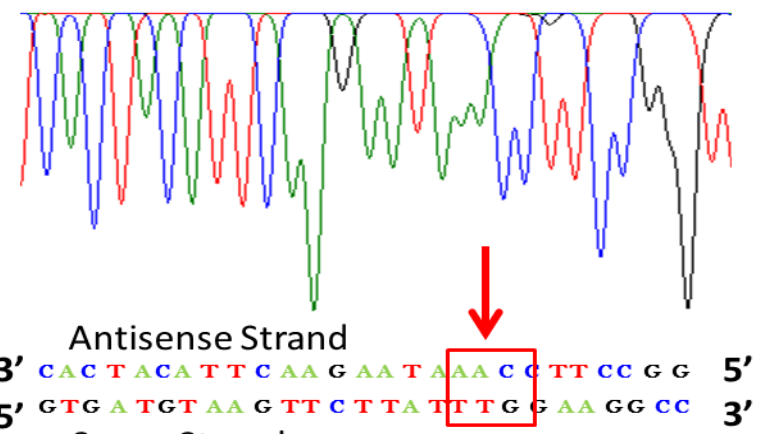

Sense Strand

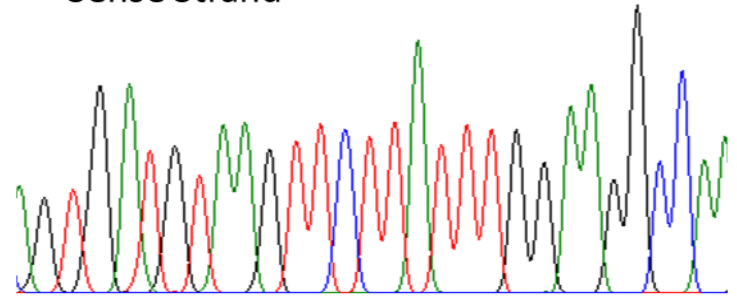

Figure 2. the electropherogram of the result of capillary electrophoresis shows the normal sequence (wild type) of the gene of GLP-1 refers to coding region accession no NC_000002.12, the DNA sequence of antisense strand around Leu111 is 5' GGCCTTCCAAATAAGAACTTACATCAC 3' while the sense strand is GTGATGTAAGTTCTTATTTGGAAGGCC 3'.

This results indicate that soybean supplementation have no effect in increasing blood glucose level for diabetic subjects. Most of blood glucose levels in the two groups were more than $200 \mathrm{mg} / \mathrm{dL}$, while some were below $200 \mathrm{mg} / \mathrm{dL}$. But the NNT (Number Needed to Treat) value between the supplement versus the placebo group was statistically not significant. Therefore, the use
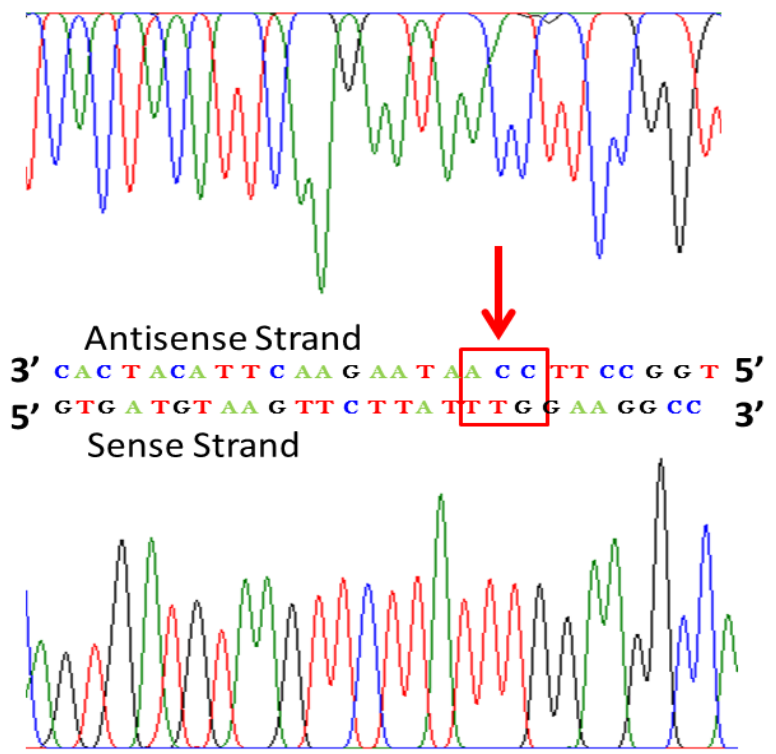

Figure 3. the electropherogram of the result of capillary electrophoresis shows the abnormal sequence of the gene of GLP-1, in the red box it visible to be lost one nucleotide (Adenine) compare to figure 1 . In this electropherogram sequence of the antisense strand change to 5' GGCCTTCC-AATAAGAACTTACATCAC 3' while the sense strand still unchanged it same with the reference GTGATGTAAGTTCTTATTTGGAAGGCC 3'.

of soy-based supplements containing $18 \mathrm{~g}$ of protein cannot be recommended as a specific therapy to control blood glucose levels in patients with T2DM. However, its use as a substitute for breakfast or dinner can still be suggested based on the average increase in glucose after the treatment of soy-based supplements, which was only $28.9 \pm 6.6 \mathrm{mg} / \mathrm{dL}$. 
Table VI. Difference in blood insulin levels and blood glucose levels in soy supplementation based on GPL1 genetic variations of antisense strand NC_000002.12: g.162145600delA.

\begin{tabular}{lcccccc}
\hline \multirow{2}{*}{ Group } & \multicolumn{2}{c}{$\begin{array}{c}\text { Average } \pm \text { SEM difference blood insulin } \\
\text { level }(\boldsymbol{\mu U} / \mathbf{m L})\end{array}$} & \multicolumn{2}{c}{$\begin{array}{c}\text { Average } \pm \text { SEM difference blood } \\
\text { Glucose Level (mg/dL) }\end{array}$} \\
\cline { 2 - 7 } & Suplement & Placebo & p-value & Suplement & Placebo & p-value \\
\hline AA (n) & $7.2 \pm 2.9(6)$ & $1.1 \pm 0.9(10)$ & $<0.05$ & $133.6 \pm 36.5(6)$ & $153.4 \pm 18.7$ & $>0.05$ \\
DelA (n) & $4.9 \pm 0.8(31)$ & $(-0.9 \pm 0.5)$ & $<0.05$ & $129.4 \pm 12.2(31)$ & $143.5 \pm 9.7$ & $>0.05$ \\
& & $(27)$ & & & $(27)$ & \\
\hline
\end{tabular}

SEM: Standard Error Mean blood insulin level, $\eta^{2}=0.41 p<0.05$, Mean blood glucose level, $\eta^{2}=0.02 p>0.05$,

The changes of blood insulin and glucose level in the subject who do not use insulin during routine therapy (Table IV and V). It can be seen that the changes of the both parameter after supplementation and or after 2h-meal (2pp) exhibited similarity with the changes of those in all subjects involved, both subject with and without insulin during DM therapy. The result of DNA isolation of GLP-1 gene which amplified by PCR shows an image of amplification of DNA of GLP-1 (37 amino acid) gene as band of $137 \mathrm{bp}$ length of PCR product on gel electrophoresis (Figure 1).

The sequencing results of the gene of GLP-1 (37 amino acid) showed a difference of nucleotide sequences in the antisense strand than a normal reference which is CAA $>\mathrm{C}-\mathrm{A}$ found in a most subject which coincided with the $111^{\text {th }}$ amino acid of glucagon preproprotein, leucine (Leu111). The Leu111 mRNA coding which is the sense strand is TTG. The normal double-stranded DNA according to accession number NC_000002.12 precisely around the Leu111 of glucagon preproprotein (Figure 2).

In this study, it was found that GLP-1 (37 amino acid) sequencing examination showed abnormalities, antisense strand DNA sequences that coincided with the $111^{\text {th }}$ amino acid of glucagon preproprotein precisely at the chromosome position NC_000002.12:g.162145600delA. Normal reference sequence of antisense strands nucleotide number 162145599-162145601 is 5'CAA3' but the results of the examination found the subjects shows $5^{\prime} \mathrm{C}-\mathrm{A} 3$ ' sequences (Figure 3 ).

There has never been reported a single nucleotide variation $(\mathrm{SNV})$ of deletion $(\mathrm{CAA}>\mathrm{C}-\mathrm{A})$ at the position of the amino acid Leu111 from the glucagon preproprotein gene. The NCBI Reference shows that the nucleotide variation associated with the Leu111 amino acid that exists is substitution on antisense strand $\mathrm{CAA}>\mathrm{CAG}$ which it sense strand $\mathrm{TTG}>\mathrm{CTG}$, it SNV is synonymous encoding leucine amino acids and its occurrence is very rare with minor allele frequency (MAF) less than 0.0001 . Deletion at the position NC_000002.12:g.162145600delA in diabetics patients of the Javanese may relate to the changes of insulin levels need require more extensive and more rigorous study, so far, these single nucleotide variations have not been reported at all. However, if indeed the deletion exists even though it has not been disturbed clinically so the absence of nucleotides on one side of the DNA strand will make an unstable DNA. This condition allows other nucleotides to be occupied or a pair of nucleotides will disappear and affect the protein product when DNA transcribed and then translated in the process of protein synthesis. Finally, the amino acid composition of protein products may change and may affect its function clinical manifest as a disorder or disease. Theoretically adenine deletion on antisense strand position NC_000002.12:g.162145600delA may change amino acid sequence (DVSSYlegqaakefiawlvk...(+55 amino acids)...*>DVSSYwkaklprnsllgw*) so it will influent the GLP1 function. In this study, the administration of supplement change insulin level $\left(\eta^{2}=0.40 p<0.05\right)$, the changes may/may not relate to genetic variation. The increase in blood insulin levels after the soybean supplement treatment appeared to be higher in the normal genotype group of $7.1 \pm 2.9 \mu \mathrm{IU} / \mathrm{mL}(\mathrm{n}=6)$ compared to the abnormal (mutant) genotype group of $4.9 \pm 0.7 \mu \mathrm{IU} / \mathrm{mL}$ $(n=29)$ the correlation $\eta^{2}=0.41$ statistically significance $(p<0.05)$. More clearly with respect to subjects with normal and abnormal DNA sequences to insulin levels and blood glucose levels both in the treatment group of soybean supplements and the control group can be observed (tables VI). 


\section{CONCLUSION}

From the study, it can be concluded that there is a relationship between the administration of soybean supplements and the changes of blood glucose and insulin levels. Genetic variation in normal genotypes of GLP-1 at the position of the antisense strand NC_000002.12: g.162145600delA may relate to the cganges blood insulin levels. The administration of soy-based supplements containing 18g of protein increased blood insulin levels and suppressed blood glucose levels but cannot reversed back to normal levels. Although it cannot be used as specific therapy in Type 2 diabetes mellitus, one serving supplement as a substitute for a meal can be recommended without anti-diabetic medications if the basal glucose level is normal.

\section{ACKNOWLEDGEMENT}

This study project was supported by Directorate of Study and Community Services, Ministry of Study, Technology and Higher Education, Republic of Indonesia Grant number: 109/SP2H/LT/DRPM/ 2019.

\section{REFERENCES}

Baequny A., Hartono M., and Harnany AS. 2015. Efek Pemberian Susu Kedelai Terhadap Kadar Gula Darah Penderita Diabetes Mellitus Tipe 2. Jurnal Informasi Kesehatan Indonesia (Jiki), 1, 89-96.

Balitbangkes. 2013. Riset Kesehatan Dasar (RISKESDAS 2013). Badan Penelitian Dan Pengembangan Kesehatan Kementerian Kesehatan RI, 1-384. https://doi.org/1 Desember 2013

Bowen J., Noakes M. and Clifton PM. 2006. Appetite regulatory hormone responses to various dietary proteins differ by body mass index status despite similar reductions in ad Libitum energy intake. J Clin Endocrinol Metab, 91(8), 2913-2919. https://doi.org/10.1210/jc.2006-0609

Cahyono AD. 2011. Manfaat susu kedelai sebagai terapi penurun kadar glukosa darah pada klien diabetes mellitus. Jurnal AKP, 2(4), 2837.

Chang C., Lin Y., Bartolome A., Chen Y-C., Chiu S-C., Yang W-C. 2013. Herbal Therapies for Type 2 Diabetes Mellitus: Chemistry, Biology, and Pote...: EBSCOhost. Evidence-Based Complementary and Alternative Medicine, 2013, 1-33. https://doi.org/http://dx.doi.org/10.1155/

\section{$2013 / 378657$}

Chang JH., Kim MS., Kim TW. and Lee SS. 2008. Effects of soybean supplementation on blood glucose, plasma lipid levels, and erythrocyte antioxidant enzyme activity in type 2 diabetes mellitus patients. Nutrition Research and Practice, 2(3), 152-7. https://doi.org/10.4162/nrp.2008.2.3.152

Delima D., Widowati L., Astuti Y., Siswoyo H., Gitawati R. and Purwadianto A. 2012. Gambaran Praktik Penggunaan Jamu Oleh Dokter di Enam Provinsi Di Indonesia. Bul. Penelit. Kesehat, 40(3), 109 - 122. Retrieved from

https://www.mysciencework.com/publicat ion/read/1835049/gambaran-praktikpenggunaan-jamu-oleh-dokter-di-enamprovinsi-di-indonesia\#page-null

Ding M., Pan A., Manson JE., Willett WC., Malik V., Rosner B., et al., 2016. Consumption of soy foods and isoflavones and risk of type 2 diabetes: A pooled analysis of three US cohorts. EJCN, 70(12), 1381-1387. https://doi.org/10.1038/ejcn.2016.117

Douglas SM., Lasley TR. and Leidy HJ. 2015. Consuming Beef vs. Soy Protein Has Little Effect on Appetite, Satiety, and Food Intake in Healthy Adults. Journal of Nutrition, 145(5), 1010-1016. https://doi.org/10.3945/jn.114.206987

Herman MJ., Supardi S. and Handayani RS. 2013. Policy on Herbal Traditional Medicines Therapy in Three Provinces in Indonesia. Bul. Penelit. Kesehat, 41(2), 111-119.

International Diabetes Federation (IDF). (2015). IDF Diabetes Atlas. International Diabetes Federation (Seventh Ed). https://doi.org/10.1289/image.ehp.v119.i0 3

Janus CC., Jacob N., Albrechtsen W. and Holst JJ. 2019. GLP-1 defects in diabetes The incretin effect is impaired in subjects with T2D GLP1 defects in subjects with T2D. Diapedia, 1 , 3-8.

https://doi.org/10.14496/dia.0104336116. 6

Jiang S., Zhai H., Li D., Huang J., Zhang H., Li, Z., et al., 2016. AMPK-dependent regulation of GLP1 expression in L-like cells. Journal of Molecular Endocrinology, 57(3), 151-160. https://doi.org/10.1530/JME-16-0099

Khardori R. 2016. Type 2 Diabetes Mellitus. Comparative and General Pharmacology, 121. Retrieved from 
http://emedicine.medscape.com/article/11 7853-overview\#a5

Kwak JH., Lee JH., Ahn C-W., Park S.-H., Shim S-T., Song YD., et al., 2010. Black soy peptide supplementation improves glucose control in subjects with prediabetes and newly diagnosed type 2 diabetes mellitus. J Med Food, 13(6), 1307-1312. https://doi.org/10.1089/jmf.2010.1075

Li W., Ruan W., Peng Y., and Wang D. 2018. Soy and the risk of type 2 diabetes mellitus: A systematic review and meta-analysis of observational studies. Diabetes Res. Clin. Pract., 137, 190-199. https://doi.org/10.1016/j.diabres.2018.01. 010

Liu D., Zhen W., Yang Z., Carter JD., Si H. and Reynolds KA. 2006. Genistein acutely stimulates insulin secretion in pancreatic ??cells through a cAMP-dependent protein kinase pathway. Diabetes, 55(4), 10431050.

https://doi.org/10.2337/diabetes.55.04.06. db05-1089

Mansour A., Hosseini S., Larijani B., Pajouhi M. and Mohajeri-Tehrani MR. 2013. Nutrients related to GLP1 secretory responses. Nutrition, 29(6), 813-820. https://doi.org/10.1016/j.nut.2012.11.015

Moghaddam AS., Entezari MH., Iraj B., Askari G., Sharifi ZE., and Maracy MR. 2014. The Effects of Soy Bean Flour Enriched Bread Intake on Anthropometric Indices and Blood Pressure in Type 2 Diabetic Women: A Crossover Randomized Controlled Clinical Trial. Int J Endocrinol, 5(12), 1529-1536. https://doi.org/10.1155/2014/240760

Nguyen CT., Pham NM., Do VV., Binns C. W., Hoang VM., Dang D A. and Lee AH. 2017. Soyfood and isoflavone intake and risk of type 2 diabetes in Vietnamese adults. EJCN, 71(10), 1186-1192. https://doi.org/10.1038/ejcn.2017.76

PERKENI. (2015). Konsensus Pengelolaan dan Pencegahan Diabetes Melitus Tipe 2 di Indonesia 2015 (Juli 2015). PB. PERKENI. Retrieved from https://pbperkeni.or.id/wpcontent/uploads/2019/01/4.-KonsensusPengelolaan-dan-Pencegahan-Diabetesmelitus-tipe-2-di-Indonesia-PERKENI2015.pdf

Purnomo Y. 2018. Potensi toleransi oral glukosa ekstrak biji kedelai (Glycine max), rimpang jahe (Zingiber officinale) dan kombinasinya pada tikus model diabetes. eJKI, 7(1), 45-50. Retrieved from http://riset.unisma.ac.id/index.php/jk

Sada NM., Tanko Y., Mabrouk MA. and Sada NM. (2013). Effect of soya beans supplement on blood glucose levels and haematological indices on alloxan induced diabetic wistar rats Scholars Research Library. Annals of Biological Research, 4(2), 208-213. Retrieved from https://www.scholarsresearchlibrary.com/ articles/effect-of-soya-beans-supplementon-blood-glucose-levels-andhaematologicalindices-on-alloxan-induceddiabetic-wistar-rat.pdf

Sathyapalan T., Rigby AS., Bhasin S., Thatcher NJ., Kilpatrick ES. and Atkin SL. 2017. Effect of soy in men with type 2 diabetes mellitus and subclinical hypogonadism: A randomized controlled study. J Clin Endocrinol Metab, 102(2), 425-433. https://doi.org/10.1210/jc.2016-2875

Sinaga, E., \& Wirawanni, Y. (2013). Pengaruh pemberian susu kedelai terhadap kadar glukosa darah puasa pada wanita prediabet. Journal of Nutrition College, 2(1), 312-321. Retrieved from http://ejournals1.undip.ac.id/index.php/jnc

Sun L., Tan KWJ., Siow PC. and Henry CJ. 2016. Soya milk exerts different effects on plasma amino acid responses and incretin hormone secretion compared with cows' milk in healthy, young men. British Journal of Nutrition, 116(07), 1216-1221. https:// doi.org/10.1017/s0007114516003214

Talaei M. 2015. Role of phytoestrogens in prevention and management of type 2 diabetes. World J Diabetes, 6(2), 271-283. https://doi.org/10.4239/wjd.v6.i2.271

Tulk B., Li J., McGraw N., Napawan N., Ghosh P. and Krul E. 2014. Identification of a bioactive peptide from Glycine max that stimulates the release of cholecystokinin and glucagon-like peptide-1 from enteroendocrine cells (372.1). Faseb J, 28(1_Supplement), 372.1-. Retrieved from http://www.fasebj.org/cgi/content/long/2 8/1_Supplement/372.1

Zhang XM., Zhang YB. and Chi MH. 2016. Soy protein supplementation reduces clinical indices in type 2 diabetes and metabolic syndrome. Yonsei Medical J, 57(3), 681-689. https://doi.org/10.3349/ymj.2016.57.3.68 1 